\title{
Pramlintide for diabetes mellitus (Protocol)
}

\author{
Barbonta DH, Loughlan CW, Dickerson JEC
}

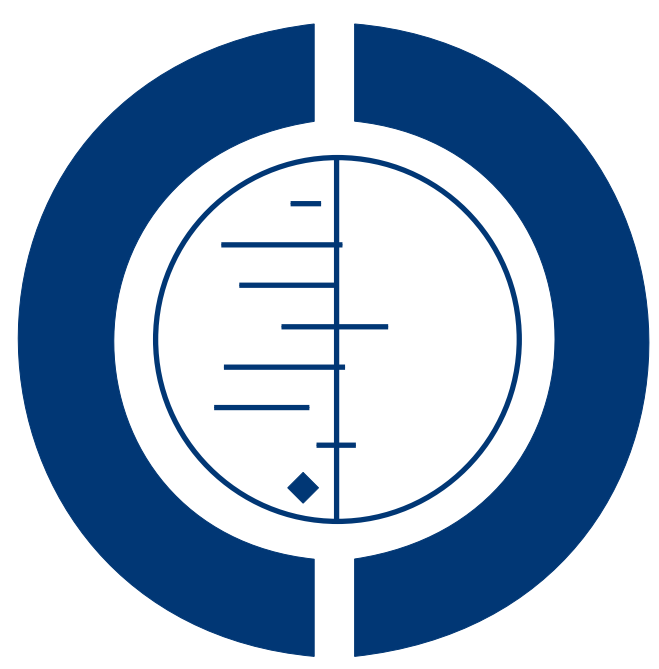

\section{THE COCHRANE COLLABORATION $^{\circledR}$}

This is a reprint of a Cochrane protocol, prepared and maintained by The Cochrane Collaboration and published in The Cochrane Library 2010, Issue 2

http://www.thecochranelibrary.com

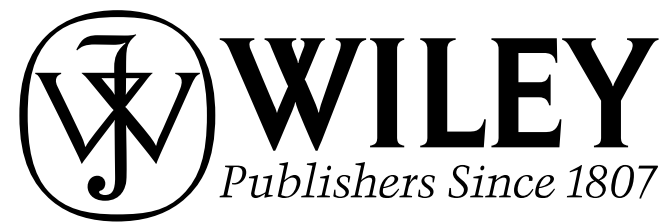


TABLE OF CONTENTS

HEADER . . . . . . . . . . . . . . . . . . . . . . . . . . . . . . . . . . . . . . . . 1

ABSTRACT . . . . . . . . . . . . . . . . . . . . . . . . . . . . . . . . . . . . . . . . . . . . . . .

BACKGROUND . . . . . . . . . . . . . . . . . . . . . . . . . . . . . . . . . . . . . . . . . . . . .

OBJECTIVES . . . . . . . . . . . . . . . . . . . . . . . . . . . . . . . . . . . . . 3

METHODS . . . . . . . . . . . . . . . . . . . . . . . . . . . . . . . . . . . . . . 3

ACKNOWLEDGEMENTS . . . . . . . . . . . . . . . . . . . . . . . . . . . . . . . . . . . . . . . . 8

REFERENCES . . . . . . . . . . . . . . . . . . . . . . . . . . . . . . . . . . . . . 8

ADDITIONAL TABLES . . . . . . . . . . . . . . . . . . . . . . . . . . . . . . . . . . 10

APPENDICES . . . . . . . . . . . . . . . . . . . . . . . . . . . . . . . 12

HISTORY . . . . . . . . . . . . . . . . . . . . . . . . . . . . . . . . . . . . . . . 19

CONTRIBUTIONS OF AUTHORS . . . . . . . . . . . . . . . . . . . . . . . . . . . . . . . . . . . . . . 19

DECLARATIONS OF INTEREST . . . . . . . . . . . . . . . . . . . . . . . . . . . . . . . . 19

SOURCES OF SUPPORT . . . . . . . . . . . . . . . . . . . . . . . . . . . . . . . . . . . . . . 19

NOTES . . . . . . . . . . . . . . . . . . . . . . . . . . . . . . . . . . . . . . . . 19 


\section{[Intervention Protocol]}

\section{Pramlintide for diabetes mellitus}

Diana Hortensia Barbonta ${ }^{1}$, Christopher William Loughlan ${ }^{2}$, JE Claire Dickerson ${ }^{3}$

${ }^{1}$ Endocrinology, Diabetes and Metabolic Disorders Department, Emergency Hospital Alba, Alba-Iulia, Romania. ${ }^{2}$ Research, Cambridge Institute for Research, Education and Management, Cambridge, UK. ${ }^{3}$ School of Education, University of Hertfordshire, Hatfield, UK

Contact address: Diana Hortensia Barbonta, Endocrinology, Diabetes and Metabolic Disorders Department, Emergency Hospital Alba, 23, 1989 Revolutiei Blvd., Alba-Iulia, Transylvania, 510053, Romania. dianabarbonta@yahoo.com.

Editorial group: Cochrane Metabolic and Endocrine Disorders Group.

Publication status and date: New, published in Issue 2, 2010.

Citation: Barbonta DH, Loughlan CW, Dickerson JEC. Pramlintide for diabetes mellitus. Cochrane Database of Systematic Reviews 2010, Issue 2. Art. No.: CD008383. DOI: 10.1002/14651858.CD008383.

Copyright (C) 2010 The Cochrane Collaboration. Published by John Wiley \& Sons, Ltd.

\section{A B S T R A C T}

This is the protocol for a review and there is no abstract. The objectives are as follows:

To assess the effects of pramlintide for diabetes mellitus. 


\section{B A C K G ROU N D}

\section{Description of the condition}

The World Health Organisation defines diabetes mellitus as a metabolic disorder characterised by chronic hyperglycaemia with disturbances of carbohydrate, fat, and protein metabolism resulting from defects in insulin secretion, insulin action or both. The effects of diabetes mellitus include long-term damage, dysfunction and failure of various organs (WHO 1998).

Of the major aetiological forms of diabetes mellitus, type 1 and type 2 diabetes account for the majority of cases. In both type 1 and type 2 diabetes there is a decline in the secretory function of pancreatic beta-cells. In type 1 diabetes the decline in insulin secretion to an absolute deficit of insulin is usually rapid and it is due to an autoimmune process or, less frequently, to unknown, idiopathic destruction of pancreatic beta-cells. In type 2 diabetes mellitus two processes coexist and interact over the course of the disease: insulin resistance - that is a diminished effect of insulin and insulin deficiency (Kahn 2003). Insulin resistance in type 2 diabetes is frequently related to overweight and obesity. In type 2 diabetes insulin secretion failure is usually slow compared to type 1 diabetes with a progressive loss of beta-cells function and betacells mass due to yet unknown causes, other than autoimmunity but eventually determining the need for exogenous insulin administration to correct chronic hyperglycaemia (Weir 2004).

Since the discovery of insulin made survival in diabetes possible accumulating epidemiological evidence demonstrated the causal relationship between hyperglycaemia and diabetes specific complications like retinopathy with the potential evolution to blindness, nephropathy potentially leading to end-stage renal failure and neuropathy. The effect of treating hyperglycaemia in preventing the development and progression of diabetes complications was convincingly demonstrated by two landmark trials - the DCCT in type 1 diabetes (DCCT 1993) and the UKPDS in type 2 diabetes (UKPDS 1998)

Cardiovascular disease due to premature and extensive atherosclerosis is increased in both type 1 and type 2 diabetes. Intensive treatment of hyperglycaemia was demonstrated to have a beneficial long term effect on cardiovascular morbidity and mortality in type 1 diabetes (DCCT/EDIC 2005). Major cardiovascular events as sudden death, myocardial infarction, stroke are the most important causes of death among type 2 diabetic patients. Treating hyperglycaemia in type 2 diabetes decreases cardiovascular risk (UKPDS 1998; UKPDS-80 2008). Nevertheless, the current outlook of the medical community on treatment in type 2 diabetes is a multifactorial, integrated approach with an early and intensive control of all the contributing cardiovascular risk factors of which hyperglycaemia is one factor (Gaede 2004). Of these factors, hyperglycaemia appears to be the most difficult to control . Recently published results from three large randomised clinical trials have drawn attention upon: the potential risk associated with treatment induced hypoglycaemia and, possibly, other safety aspects of multiple associated therapies in type 2 diabetes (ACCORD 2008) the beneficial effect and relative safety of early interventions on glycaemic control in the development of microvascular complications such as nephropathy and on macrovascular outcomes (ADVANCE 2008; ADVANCE 2009) as compared to the ineffectiveness of late intervention on glycaemic control in the progression of cardiovascular disease (VADT 2009).

For a detailed overview of diabetes mellitus, please see under 'Additional information' in the information on the Metabolic and Endocrine Disorders Group in The Cochrane Library ( see 'About', 'Cochrane Review Groups (CRGs)').For an explanation of methodological terms, see the main glossary in The Cochrane Library.

\section{Description of the intervention}

\section{The importance of treating postprandial hyperglycaemia in diabetes mellitus}

Diabetes related complications develop over many years or decades from diagnosis. Therefore, glycosylated haemoglobin (HbA1c) is used as a predictive measurement for developing diabetes related complications as well as a measurement of drugs' effect - evaluative instrument - in treating hyperglycaemia in clinical practice (ADA 2008). A widespread use of HbA1c changes with treatment is that of a 'surrogate endpoint ' in diabetes-drugs approval trials (Bucher 2008). Glycosylated haemoglobin is a composite measurement incorporating information on fasting, inter-prandial glycaemic values and post-prandial glycaemic excursions. Due to deficient insulin secretion or a combination of inadequate insulin secretion and an altered insulin action in diabetes, post-prandial glycaemic increases are of higher amplitude and last much longer compared to non-diabetic persons, making a larger contribution to the overall glycaemic control as expressed by $\mathrm{Hb} \mathrm{A1c}$ (Monnier 2006; Monnier 2009). Recent experimental work and expert opinion suggest a possible independent role for postprandial hyperglycaemia in the development of late complications in diabetes (Cerriello 2005).

In type 1 diabetes glycaemic control can be achieved by insulin administration either as multiple daily injections or by continuous subcutaneous insulin infusion (CSII), with short or rapid acting insulin delivered at meals or by increasing the rate of insulin infusion as to prevent postprandial glycaemic raises. Pramlintide addition to mealtime insulin may be another choice in treating postprandial hyperglycaemia in type 1 diabetes.

In type 2 diabetes there is a wide armamentarium of antidiabetic drugs to decrease glycaemic values, with new drugs and new classes of drugs reaching the market continuously (Nathan 2007; Nathan 2009). Some classes of drugs target specifically postprandial hyperglycaemia: alfa-glucosidase inhibitors such as acarbose 
and miglitol, meglitinides such as repaglinide and nateglinide. Of the traditional classes of antidiabetic drugs, both sulphonylurea and metformin exert lowering effects on postprandial glycaemic values. Exenatide - the first approved compound of a new class of drugs - the GLP-1 agonists- appears to lower more efficiently postprandial glycaemia than fasting glycaemia. The effect of these agents depends largely on the stage of beta-cell dysfunction in type 2 diabetes. In some patients with type 2 diabetes postprandial glucose control can be achieved only by prandial insulin administration, either premixed with longer acting insulins or as short or rapid-acting insulin administered before meals. Pramlintide has also been approved for use as adjunct therapy to mealtime insulin in type 2 diabetes. Therapies aiming at lowering postprandial glycaemia - such as sulphonylurea, prandial insulin and meglitinides - also induce variable weight increase. This effect is not observed with $\alpha$-glucosidase inhibitors, metformin, exenatide and pramlintide, these drugs appear to induce a variable weight reduction. As the majority of type 2 diabetic patients are overweight and obese, weight gain with therapy in type 2 diabetes is undesirable and may be deleterious .

\section{How the intervention might work}

Pramlintide was approved for use by the U.S. FDA in 2005, as an adjunct therapy to mealtime insulin, aimed at decreasing postprandial glucose values in patients with type 1 and type 2 diabetes mellitus that can not achieve the desired glycaemic goals with insulin only (U.S. FDA 2009).

Pramlintide was developed following the discovery in 1987 of amylin, a polypeptide co-produced and co-secreted with insulin by the beta -cells of the pancreas. Amylin has been demonstrated to produce additional effects to insulin in lowering plasma glucose. Synthesis and secretion of amylin parallel that of insulin and amylin is deficient in diabetes.

As native amylin is unstable and has a tendency to aggregate and form macromolecules, a synthetic, stable derivative was developed as pramlintide acetate. Early clinical studies have demonstrated the pharmacological effects of pramlintide that determine the drug's beneficial role in decreasing postprandial glucose values: delayed gastric emptying determining a slower appearance of nutrients in plasma (Kong 1997; Thompson 1997) increasing satiety partly due to delayed gastric emptying; inhibition of excessive glucagon secretion possibly by a direct effect on the alfa-cells of the pancreas (Fineman 2002; Nyholm 1999). More recently, a possible central neural effect of pramlintide on specific amylin receptors with potential therapeutic applications was conceptualised (Roth 2009). Randomised clinical trials have further confirmed the beneficial effects of pramlintide in both type 1 and type 2 diabetes as well as the potential adverse effects of the drug. A decrease in postprandial glucose levels and a decrease in HbA1c levels accompanied by weight loss was reported in both type 1 and type 2 diabetic patients treated with pramlintide.
Pramlintide is administered prior to meals, by subcutaneous injections. In type 1 diabetes, recommended doses are $15 \mathrm{mcg}$ per dose to $60 \mathrm{mcg}$ per dose, with a stepwise increase starting with the lowest dose of $15 \mathrm{mcg}$. In type 2 diabetes, recommended doses are $60 \mathrm{mcg}$ per dose to $120 \mathrm{mcg}$ per dose following the same stepwise increase of dosage. Adjustments of insulin dose at meals are recommended with possible decreases if needed especially in the beginning of the treatment.

\section{Adverse effects of the intervention}

In clinical trials the most frequently reported adverse events were nausea and gastrointestinal disturbances sometimes leading to withdrawal of participants. Hypoglycaemic events are more frequent in type 1 diabetes and occur about three hours following meals. Risk of severe hypoglycaemia and hypoglycaemia- related events (such as motor vehicle accidents) have determined the label warning on this risk as well as the recommendation that pramlintide should be used under strict surveillance of a specialised, experienced diabetes team, only in patients without known hypoglycaemia unawareness or gastroparesis or other gastric motility disturbances. In addition, patients using pramlintide should be carefully instructed on identifying and promptly treating hypoglycaemic episodes.

\section{Why it is important to do this review}

Pramlintide is a controversial and possibly under-explored drug in diabetes mellitus. One health technology assessment (McQueen 2005) and two systematic reviews on pramlintide for diabetes mellitus were published (Nogid 2006; Singh-Franco 2007). Since the date of their publication, randomised clinical trials exploring new ways of use for pramlintide in diabetes mellitus have published their results (Riddle 2007; Riddle 2009) and other post-marketing randomised clinical trials are ongoing.

Our aim in doing this review is to identify and aggregate the good quality evidence on pramlintide for diabetes mellitus. We will also try to assess aspects like effects of pramlintide on health-related quality of life, tolerance and acceptability of treatment and cost related issues if feasible- as these aspects are important contributors to the strength of recommendation for use of pramlintide in diabetes.

\section{O B J E C T I V E S}

To assess the effects of pramlintide for diabetes mellitus. 


\section{Criteria for considering studies for this review}

\section{Types of studies}

Randomised controlled clinical trials of any design.

\section{Types of participants}

Type 1 and type 2 diabetic patients will be included, irrespective of age (over 18 as well as under 18 year old), gender or race.Type 2 diabetic patients both insulin-treated and non-insulin- treated, regardless of background antidiabetic therapy will be included.

\section{Diagnostic criteria}

To be consistent with changes in classification and diagnostic criteria of diabetes mellitus through the years, the diagnosis should have been established using the standard criteria valid at the time of the beginning of the trial (for example ADA 1997; ADA 1999; WHO 1980; WHO 1985; WHO 1998). Ideally, diagnostic criteria should have been described. If necessary, authors' definition of diabetes mellitus will be used. Diagnostic criteria will be eventually subjected to a sensitivity analysis.

\section{Types of interventions}

\section{Intervention}

- pramlintide alone or added to short or rapid acting insulin (administered prior to meals by subcutaneous injection, in doses ranging from $15 \mathrm{mcg}$ per dose to $120 \mathrm{mcg}$ per dose, with a duration of intervention of at least 12 weeks).

\section{Comparisons}

- placebo;

- intensification of 'life-style' interventions;

- continuous subcutaneous insulin infusion (CSII);

- intensification of insulin treatment;

- oral antidiabetic drugs ( $\alpha$-glucosidase inhibitors, meglitinides, sulphonylurea, metformin);

- exenatide;

- no intervention.

Comparisons were selected based on the clinical rationale of targeting postprandial hyperglycaemia.

\section{Types of outcome measures}

\section{Primary outcomes}

- overall glycaemic control as measured by glycosylated haemoglobin A1c (HbA1c);
- hypoglycaemia; hypoglycaemic events will be graded as: mild (symptoms easily controlled by individual), moderate(normal activities interrupted but not requiring assistance), severe (individual requiring assistance and associated with blood glucose levels less than $50 \mathrm{mg} / \mathrm{dL}(4 \mathrm{mmol} / \mathrm{L})$ or prompt recovery after carbohydrate or glucagon administration) (DCCT 1993). Classification of hypoglycaemic events as defined by clinical trial protocols will also be considered and assessed;

- weight change as measured by body mass index or weight or both.

\section{Secondary outcomes}

- mortality (death from any cause; diabetes related death death from myocardial infarction, stroke, peripheral vascular disease, renal disease, hyper- or hypoglycaemia, sudden death);

- morbidity (morbidity from any cause; diabetes and cardiovascular related morbidity - angina pectoris, myocardial infarction, heart failure, renal failure, stroke, peripheral arterial disease, neuropathy, retinopathy, erectile dysfunction, amputation, blindness, vitreous haemorrhage, cataract);

- adverse events; adverse events will be considered as any untoward medical occurrence not necessarily having a causal relationship with the treatment. Serious adverse events will be defined as any adverse event that results in death, is immediately life-threatening, requires hospitalisation, or prolongation of hospitalisation, results in persistent or significant disability or incapacity, results in congenital anomaly or birth defect (as defined by ICH 1997). Adverse events leading to patient withdrawal will be assessed. Hypoglycaemic events or hypoglycaemia-related adverse events will be considered 'primary outcomes ' and assessed separately;

- fasting and postprandial glucose;

- health-related quality of life (using a validated instrument);

- tolerance and acceptability of treatment;

- costs of treatment.

\section{Covariates, effect modifiers and confounders}

- HbAlc values at baseline (eg lower or higher than $8 \%$ );

- body mass index (BMI);

- age;

- diabetes onset, ie time from diagnosis;

- gender;

- race;

- co-morbidities;

- co-medication;

- duration of intervention.

\section{Timing of outcome measurement}

We will assess outcomes in the short term (equal or more than 12 weeks to less than 18 weeks), medium term (equal or more 
than 18 weeks to less than 52 weeks) and long term (equal or more than 52 weeks). Data from long- term extension trials of randomised controlled trials will be considered only if participants are maintaining the same sequence allocation as in the initialfeeder- trial.

\section{Search methods for identification of studies}

We will identify studies according to Cochrane Metabolic and Endocrine Disorders Group methods used in reviews.

\section{Electronic searches}

We will use the following sources for the identification of trials:

- The Cochrane Library (latest issue);

- MEDLINE - (until recent);

- EMBASE - (until recent).

We will also search other databases:

- Current Controlled Trials - www.controlled-trials.com -

with links to other databases of ongoing trials;

- National Institutes of Health (NIH)/ National Library of Medicine (NLM) - www.clinicaltrials.gov;

- Intenational Foundation of Pharmaceutical Manufacturers \& Associates (IFPMA) - www.ifpma.org;

- www.ClinicalStudyResults.org.

For detailed search strategies please see under Appendix 1. Additional key words of relevance may be detected during any of the electronic or other searches. If this is the case, electronic search strategies will be modified to incorporate these terms. Studies published in any language will be included.

\section{Searching other resources}

We will thoroughly search the U.S. Food and Drug Administration (U.S. FDA) site for data on pre-approval trials. Documentation submitted for drug approval will be appraised, matched with published reports, appraised for unpublished data. If needed, the authors of the review will contact the FDA medical officer signing the FDA medical review for clarification and details (U.S. FDA 2009).

In addition,we will search the American Diabetes Association (ADA) site and meetings abstracts as well as the European Association for the Study of Diabetes (EASD) site and meetings abstracts. We will also search manufacturer 's site and we will contact manufacturer's representatives responsible with sponsor-funded trials conduct for potential unpublished or incompletely available information from published trials.

We will try to identify additional studies by searching the reference lists of included trials and (systematic) reviews, meta-analyses and health technology assessment reports noticed.

\section{Data collection and analysis}

\section{Selection of studies}

To determine the studies to be assessed further, two authors (D.B., C.L.) will independently scan the abstract, title or both of every record retrieved. All potentially relevant articles will be investigated as full text. We will consider potentially relevant articles in a sensitive, over-inclusive manner at first stage.

We will classify as eligible if:

- studies are randomised controlled trials;

- pramlintide is the intervention being compared;

- studies include diabetic patients.

Studies will be rejected as ineligible if:

- they are not randomised controlled trials (for example pooled post-hoc analysis of data from two or more trials);

- they include non-diabetic patients (for example obese nondiabetic patients);

- they evaluate a co-intervention (for example pramlintide plus metreleptin) or an intervention administered in another way than specified (dose, route, frequency of administration);

- the follow up period is less than 12 weeks - the time needed for $\mathrm{HbA1c}$ changes to become clinically relevant;

- none of the outcomes of interest is measured (for example biological markers or pharmacokinetics of drug only).

Interrater agreement for study selection will be measured using the kappa statistic (Cohen 1960). Differences will be marked and if these studies are late on included, the influence of the primary choice will be subjected to a sensitivity analysis. Where differences in opinion exist, they will by resolved by a third party (C.D.). If resolving disagreement is not possible, the article will be added to those 'awaiting assessment' and authors will be contacted for clarification. An adapted PRISMA (Preferred Reporting Items for Systematic Reviews and Meta-Analyses) flow-chart of study selection will be attached (Liberati 2009).

\section{Data extraction and management}

For studies that fulfil inclusion criteria, two authors (D.B., C.L.) will independently abstract relevant population and intervention characteristics using standard data extraction templates (for details see 'Characteristics of included studies' and Table 1, Appendix 2, Appendix 3, Appendix 4, Appendix 5) with any disagreements to be resolved by discussion, or if required by a third party (C.D.). Any relevant missing information on the trial will be sought from the original author(s) of the article, if required. We will also identify duplicate publications of the same report as well as companion reports by searching the reference section of reports found, searching potential other publications by the same authors and by contacting authors of the primary report. Sources of data will be specified, compared and collated in the extraction form. 


\section{Assessment of risk of bias in included studies}

Two authors (D.B., C.L.) will assess each trial independently. The reference source of information will be considered the clinical trial protocol. Ideally, clinical trial protocols should be publicly available. If this is not the case we will contact the corresponding author of the primary published report for details. Access to the original clinical trial protocol will be documented in the review and any discrepancies between the protocol and the published trial report will be acknowledged.

Assessment of risk of bias will be made at outcome level across every key- domain, within each included study and across studies according to the Collaboration's tool in assessing risk of bias. We will assess risk of bias as follows:

\section{Sequence generation}

- adequate (low risk of bias) if generated by a computerised system as a reference method - interactive voice randomisation or interactive web randomisation system (IVRS or IWRS) - other methods (coin toss, random number tables or throwing dice) are also acceptable as alternative methods of sequence generation;

- inadequate (high risk of bias) if system involves names, dates,or admittance numbers;

- uncertain if randomisation is stated in report and we can not obtain enough details.

\section{Allocation sequence concealment}

- adequate (low risk of bias) if a remote computerised system is used, interactive voice randomisation or interactive web randomisation systems (IVRS or IWRS) will be the method of reference;

- inadequate if allocation sequence is known by investigators or study is quasi-randomised;

- uncertain if allocation concealment is stated but insufficient data are available.

\section{Blinding}

Risk of bias due to blinding will be assessed in consideration to the type of outcome (Day 2000).

- adequate (low risk of bias) - for subjective outcomes (such as health-related quality of life or adverse events as nausea ) blinding of study participants and personnel as well as blinding of outcome assessors (triple blinding) should be provided; for major objective outcomes (such as death of any cause or severe hypoglycaemia) outcome assessors blinding would be sufficient; ascertainment that blinding could not be broken should be stated;
- inadequate (high risk of bias) - if study participants, personnel and outcome assessors or either of them were unblinded to treatment and outcome may be influenced by nonblinding; blinding could have been broken;

- uncertain if blinding or blinding method can not be determined from available data.

\section{Incomplete outcome data}

- adequate (low-risk of bias) - if there are no missing outcome data; if missing outcome data are unlikely related to the outcome (for example censoring for survival data ); if the proportions of missing outcome data compared with the observed event risk are unlikely to impact on the intervention effect estimate (for dichotomous data ); if the plausible effect size among missing outcomes is not enough to have a clinically relevant impact on the observed effect size (for continuous outcome data); if missing outcome data are balanced in numbers across intervention groups with similar reasons for missing data across groups and missing data are dealt with using appropriate methods;

- inadequate (high risk of bias) - if reasons for missing outcome data are likely related to true outcomes with imbalances either in numbers between treatment groups or in reasons for missing data across intervention groups; if the proportion of missing outcome data compared to the observed event risk is enough to induce bias in effect estimates (for dichotomous data); if the plausible effect size among missing outcomes is enough to induce clinically relevant bias in observed effect sizes (for continuous outcome data); if reasons for withdrawal are not explained; if only 'as treated' analysis was performed; if potentially inappropriate methods were used for dealing with missing data;

- uncertain if data on attrition and exclusion or both were not clear or sufficient and reasons for withdrawal were incomplete.

\section{Selective reporting of outcomes}

To assess selective reporting of outcomes, authors of the review will compare the 'methods' section and 'results' section of each trial report - in primary as well as companion reports identified. If possible, we will also compare outcomes data retrieved from published reports with outcomes stated in the clinical trial protocols (Chan 2004).

- adequate (low risk of bias) - if all outcomes stated in the 'methods' section of the published report of the trial overlap with the stated outcomes in the clinical trial protocol, are analysed and presented in the 'results' section of the report as stated in the protocol;

- inadequate (high risk of bias) - if one ore more pre-specified outcomes are not reported, or analysed and reported in a 
different manner than stated in the trial protocol; if one or more primary outcomes are reported that were not pre-specified (unless there is a justified reason such as an unexpected adverse event); if reporting of a major outcome is incomplete and can not be entered in a meta-analysis; if only a statement of 'nonsignificant' will be found in 'results' section; if outcomes are changed during the trial;

- uncertain if insufficient information can be obtained on outcomes.

\section{Other bias}

Early stopping for benefit will be considered 'high risk of bias' (Montori 2008a).

Baseline characteristics imbalance in the treatment groups if extreme will be considered 'high risk of bias'.

Sponsor bias will be considered if insufficient data are publicly available and access to other important information is denied by sponsor. Attempts to contact sponsor representatives responsible for the trial conduct will be documented as well as the information provided. Sponsor-bias is a complex potential source of bias that may pervade research from early stages - for example by selecting comparisons that favour intervention (Bekelman 2003; Lexchin 2003; Montori 2008b) - to reporting and dissemination of research results (Gøtzsche 2006; Graf 2009; Lexchin 2003) and may be present even if trials are of good methodological quality (Lexchin 2003).The potential influence of sponsor-bias on the overall effect of the intervention will be subject to sensitivity analysis .

Possible disagreement will be resolved by consensus, or with consultation of a third party (C.D.) in case of disagreement. Interrater agreement for key bias indicators (eg allocation concealment, incomplete outcome data) will be calculated using the kappa statistic (Cohen 1960).

\section{Measures of treatment effect}

\section{Dichotomous data}

Dichotomous data (for example number of participants achieving an $\mathrm{HbA1c}$ less than $7 \%$, number of participants experiencing a hypoglycaemic event) will be expressed as odds ratios (OR) and relative risk (RR) with $95 \%$ confidence intervals (CI).

\section{Continous data}

Continuous data (for example change of $\mathrm{HbA1c}$ from baseline, change in weight, decrease of postprandial glycaemic values) will be summarised as weighted mean difference (WMD) with 95\% CI. For studies addressing the same outcome but using different outcome measures we will use the standardized mean difference (SMD).

\section{Time to event data}

Time-to-event outcomes (for example time until development of diabetic retinopathy) will be expressed as hazard ratios (HR) with 95\% CI.

\section{Unit of analysis issues}

If RCTs of different design other than parallel arms design will be found (for example cross-over, factorial or cluster randomised trials) we will seek assistance from an experienced statistician in appraising the statistical analysis of the trial or other related issues.

\section{Dealing with missing data}

We will obtain relevant missing data by collating information from different sources (for example primary and any companion publication of the trial) and, eventually, from authors of the reports, if feasible. We will carefully perform evaluation of important numerical data such as screened, randomised patients as well as intention-to-treat (ITT) and per-protocol (PP) population. We will investigate attrition rates, for example drop-outs, losses to follow-up and withdrawals. Issues of missing data and techniques to handle these (for example, last-observation-carried-forward (LOCF)) will be critically appraised. We will also seek a statistician's assistance in appraising the method of handling missing data in included trials.

\section{Assessment of heterogeneity}

We will identify heterogeneity by visual inspection of the forest plots, by using a standard $\mathrm{Chi}^{2}$ test and a significance level of $\alpha=0.1$. In view of the low power of such tests heterogeneity will be specifically examined with the $\mathrm{I}^{2}$ statistic (Higgins 2002), where $\mathrm{I}^{2}$ values of $50 \%$ and more indicate a substantial level of heterogeneity (Higgins 2003). When heterogeneity is found, we will attempt to determine potential reasons for it by examining individual study and subgroup characteristics.

In the event of substantial clinical or methodological or statistical heterogeneity, studies will not be combined by means of metaanalysis.

\section{Assessment of reporting biases}

We will use funnel plots to assess for the potential existence of small study bias. There are a number of explanations for the asymmetry of a funnel plot (Sterne 2001). Therefore, we will carefully interpret results (Lau 2006).

\section{Data synthesis}

Data will be summarised statistically if they are available, sufficiently similar and of sufficient quality. We will perform statistical analysis according to the statistical guidelines referenced in the 
newest version of the Cochrane Handbook for Systematic Reviews of Interventions (Higgins 2009).

\section{Subgroup analysis and investigation of heterogeneity}

We will perform subgroup analyses if one of the primary outcome parameters demonstrates statistically significant differences between intervention groups. In any other case subgroup analyses will be clearly marked as a hypothesis generating exercise.

The following subgroup analyses are planned:

- type 1 and type 2 diabetes;

- age under 18 or over 18 years;

- baseline HbA1c below $8 \%$ or above $8 \%$.

Subgroup analyses will be performed, if feasible, to identify subgroups that may carry a higher risk from treatment and subgroups that may benefit more from treatment. The methodology of subgroup analyses in both randomised clinical trials and systematic reviews of interventions is still uncertain and currently under investigation (Sun 2009). We will interpret cautiously findings of subgroup analysis (Fletcher 2007) and, if necessary, will seek methodological advice.

\section{Sensitivity analysis}

We will perform sensitivity analyses in order to explore the influence of the following factors on effect size:

- repeating the analysis excluding unpublished studies;

- repeating the analysis taking account of risk of bias, as specified above;

- repeating the analysis excluding any very long or large studies to establish how much they dominate the results;

- repeating the analysis excluding studies using the following filters: diagnostic criteria, language of publication, source of funding (industry versus other), country.

We will also test the robustness of the results by repeating the analysis using different measures of effects size (relative risk, odds ratio etc.) and different statistical models (fixed-model and random-effects model).

\section{ACKNOWLEDGEMENTS}

We thank Karla Bergerhoff, the Cochrane Metabolic and Endocrine Disorders Group Trials Search Co-ordinator for the invaluable help in developing the search strategy of the review.

\section{R E F E R E N C E S}

\section{Additional references}

\section{ACCORD 2008}

Gerstein HC, Miller ME, Byington RP, Goff DC Jr, Bigger

$\mathrm{JT}$, Buse JB, et al.Effects of intensive glucose lowering in type 2 diabetes. New England Journal of Medicine 2008; 358:2545-59.

ADA 1997

American Diabetes Association. Report on the Expert Committee on the Diagnosis and Classification of Diabetes Mellitus. Diabetes Care 1997;20 Suppl 1:S5-20.

\section{ADA 1999}

The Expert Committee on the Diagnosis and Classification of Diabetes Mellitus. Report of the Expert Committee on the diagnosis and classification of diabetes mellitus. Diabetes Care 1999;22 Suppl 1:S5-19.

\section{ADA 2008}

American Diabetes Association. Standards of care in diabetes-2008(Position Statement). Diabetes Care 2008;31 (1 Suppl 1):12-54

\section{ADVANCE 2008}

Patel A, MacMahon S, Chalmers J, Neal B, Billot L, Woodward $\mathrm{M}$, et al.Intensive blood glucose control and vascular outcomes in patients with type 2 diabetes. New England Journal of Medicine 2008;358:2560-72.
ADVANCE 2009

Zoungas S, De Galan BE, Ninomiya T, Grobbee D, Hamet $P$, Heller $S$, et al.Combined effects of routine blood pressure lowering and intensive glucose control on macrovascular and microvascular outcomes in patients with type 2 diabetes; new results from the ADVANCE trial. Diabetes Care 2009; 32:2068-74

\section{Bekelman 2003}

Bekelman JE, Li Y, Gross CP. Scope and impact of financial conflicts of interest in biomedical research: a systematic review. JAMA 2003;289:454-65.

\section{Bucher 2008}

Bucher HC, Kunz R, Cook DJ, Holbrook A, Guyatt G. Surrogate outcomes. In: Guyatt G, Rennie D, Meade MO, Cook DJ editor(s). Users' guides to the medical literature: $A$ manual for evidence-based clinical practice. 2nd Edition. Chicago: The McGraw-Hill Companies, 2008:317-40.

Cerriello 2005

Ceriello A. Postprandial hyperglycaemia and diabetes complications; Is it time to treat?. Diabetes 2005;54:1-7.

Chan 2004

Chan A-W, Hróbjartsson A, Haahr MT, Gøtzsche PC, Altman DG. Empirical evidence of selective reporting of outcomes in randomised trials: comparison of protocols to published articles. JAMA 2004;291:2457-65. 


\section{Cohen 1960}

Cohen J. A coefficient of agreement for nominal scales. Educational and Psychological Measurement 1960;20:37-46.

Day 2000

Day SJ, Altman DG. Blinding in clinical trials and other studies. BMJ 2000;351:504.

\section{DCCT 1993}

Diabetes Control and Complications Trial Research Group. The effect of intensive diabetes treatment on the development and progression of long-term complications in insulin-dependent diabetes mellitus: the Diabetes Control and Complications Trial. New England Journal of Medicine 1993;329:978-86.

\section{DCCT/EDIC 2005}

Nathan DM, Cleary PA, Backlund JY, Genuth SM, Lachin JM, Orchard TJ, et al.Intensive diabetes treatment and cardiovascular disease in patients with type 1 diabetes. New England Journal of Medicine 2005;353:2643-53.

\section{Fineman 2002}

Fineman M, Weyer C, Maggs DG, Strobel S, Kolterman OG. The human amylin analog, pramlintide, reduces postprandial hyperglucagonemia in patients with type 2 diabetes mellitus. Hormone and Metabolic Research 2002; 34:504-8.

\section{Fletcher 2007}

Fletcher J. Subgroup analyses: how to avoid being misled. BMJ 2007;335:96-7.

\section{Gaede 2004}

Gaede P, Pedersen O. Intensive integrated therapy of type 2 diabetes ;Implications for long-term prognosis. Diabetes 2004;53(Suppl 3):39-47.

\section{Graf 2009}

Graf C, Battisti WP, Bridges D, Bruce-Winkler V, Conaty JM, Elliso JM, et al.Good publication practice for communicating company sponsored medical research: the GPP2 guidelines. BMJ 2009;339:1299-1303.

\section{Gøtzsche 2006}

Gøtzsche PC, Hróbjartsson A, Johansen HK, Haahr MT, Altman D, Chan AW. Constraints on publication rights in industry-initiated clinical trials. JAMA 2006;295:1645-6.

\section{Higgins 2002}

Higgins JPT, Thompson SG. Quantifying heterogeneity in a meta-analysis. Statistics in medicine 2002;21:1539-58.

\section{Higgins 2003}

Higgins JPT, Thompson SG, Deeks JJ, Altman DG. Measuring inconsistency in meta-analysis. BMJ 2003;327: 557-60.

\section{Higgins 2009}

Higgins JPT, Green S (editors). Cochrane Handbook for Systematic Reviews of Interventions Version 5.0.2 [updated September 2009]. The Cochrane Collaboration, 2009. Available from www.cochrane-handbook.org..

\section{ICH 1997}

International Conference on Harmonization Expert Working Group. International conference on harmonization of technical requirements for registration of pharmaceuticals for human use. ICH harmonised tripartite guideline. Guideline for good clinical practice 1997.

\section{Kahn 2003}

Kahn SE. The relative contributions of insulin resistance and beta -cell dysfunction to the pathophysiology of type 2 diabetes. Diabetologia 2003;46:3-19.

\section{Kong 1997}

Kong MF, King P, Macdonald IA, Stubbs TA, Perkins AC, Blackshaw PE, et al.Infusion of pramlintide, a human amylin analogue, delays gastric emptying in men with IDDM. Diabetologia 1997;40:82-8.

\section{Lau 2006}

Lau J, Ioannidis JPA, Terrin N, Schmid CH, Olkin I. The case of the misleading funnel plot. BMJ 2006;333: 597-600.

\section{Lexchin 2003}

Lexchin J, Bero LA, Djulbegovic B, Clark O. Pharmaceutical industry sponsorship and research outcome and quality: systematic review. BMJ 2003;326:1167-70.

\section{Liberati 2009}

Liberati A, Altman DG, Tetzlaff J, Mulrow C, Gøtzsche PC, Ioannidis JPA, et al.The PRISMA statement for reporting systematic and meta-analyses of studies that evaluate interventions: explanation and elaboration. PLoS Med 1999;6(7):1-28. [DOI: 10.1371/journal.pmed.1000100]

\section{McQueen 2005}

McQueen J, Bonk ME. Pramlintide acetate. American Journal of Health-System Pharmacy 2005;62 (22):2363-72.

\section{Monnier 2006}

Monnier L, Collette C, Boniface V. Contribution of postprandial glucose to chronic hyperglycaemia: from the "glucose triad" to the trilogy of "sevens". Diabetes and Metabolism 2006;26Suppl 2:11-16.

\section{Monnier 2009}

Monnier L, Collette C, Owens DR. Integrating glycaemic variability in the glycaemic disorders of type 2 diabetes : a move towards a unified glucose tetrad concept. Diabetes/ Metabolism Research and Reviews 2009;25:393-402.

\section{Montori 2008}

Montori V, Devereaux PJ, Schünemann H, Meade MO, Cook DJ, Guyatt G. Randomized trials stopped early for benefit. In: Guyatt G, Rennie D, Meade MO, Cook DJ editor(s). Users' guide to the medical literature: A manual for evidence-based clinical practice. 2nd Edition. Chicago: The McGraw-Hill Companies, 2008:153-65.

\section{Montori 2008b}

Montori V, Ioannidis J, Jaeschke R, Devereaux PJ, Schünemann $\mathrm{H}$, Bhandari $\mathrm{M}$, et al.Dealing with misleading presentations of clinical trial results; Beware faulty comparators. In: Guyatt G, Rennie D, Meade MO, Cook DJ editor(s). Users' guides to the medical literature: A manual for evidence-based clinical practice. 2nd Edition. Chicago: The Mc-Graw Hill Companies, 2008:305-7. 
Nathan 2007

Nathan DM. Finding new treatments for diabetes--how many, how fast... how good?. New England Journal of Medicine 2007;356:437-40.

Nathan 2009

Nathan DM, Buse JB, Davidson MB, Ferrannini E, Holman RR, Sherwin R, et al.Medical management of hyperglycaemia in type 2 diabetes: a consensus algorithm for the initiation and adjustment of therapy: a consensus statement of the American Diabetes Association and the European Association for the Study of Diabetes. Diabetes Care 2009;32(1):193-203.

Nogid 2006

Nogid A, Pham DQ. Adjunctive therapy with pramlintide in patients with type 1 or type 2 diabetes mellitus. Pharmacotherapy 2006;26:1626-40.

\section{Nyholm 1999}

Nyholm B, Orskov L, Hove KY, Gravholt CH, Moller N, Alberti KG, et al.The amylin analog pramlintide improves glycaemic control and reduces postprandial glucagon concentrations in patients with type 1 diabetes mellitus. Metabolism 1999;48:935-41.

Riddle 2007

Riddle M, Frias J, Zhang B, Maier H, Brown C, Lutz K, et al.Pramlintide improved glycaemic control and reduced weight in patients with type 2 diabetes using basal insulin. Diabetes Care 2007;30:2794-9.

Riddle 2009

Riddle M, Pencek R, Charenkavanich S, Lutz K, Wilhelm K, Porter L. Randomised comparison of pramlintide or mealtime insulin added to basal insulin in treatment of patients with type 2 diabetes. Diabetes Care 2009;32: 1577-82.

Roth 2009

Roth JD, Maier H, Chen S, Roland BL. Implications of amylin receptor agonism: integrated neurohormonal mechanisms and therapeutic applications. Archives of Neurology 2009;66:306-10.

\section{Singh-Franco 2007}

Singh-Franco D, Robles G, Gazze D. Pramlintide acetate injection for the treatment of type 1 and type 2 diabetes mellitus. Clinical Therapeutics 2007;29:535-62.

\section{Sterne 2001}

Sterne JAC, Egger M, Davey Smith G. Investigating and dealing with publication and other biases. In: Egger M, Davey Smith G, Altman DG editor(s). Systematic Reviews in Health Care; Meta-analysis in Context. London: BMJ Publishing Group, 2001:189-208.

Sun 2009

Sun X, Briel M, Busse JW, Akl EA, You JJ, Mejza F, et al.Subgroup Analysis of Trials Is Rarely Easy (SATIRE): a study protocol for a systematic review to characterize the analysis, reporting, and claim of subgroup effects in randomised trials. www.trialsjournal.com/content/10/1/ 101 (published 9 November 2009, accessed 12 November 2009 ).

\section{Thompson 1997}

Thompson RG, Gottlieb A, Organ K, Koda J, Kisicki J, Kolterman OG. Pramlintide: a human amylin analogue reduced postprandial plasma glucose, insulin, and peptide$\mathrm{C}$ concentrations in patients with type 2 diabetes. Diabetic Medicine 1997;14:547-55.

\section{U.S. FDA 2009}

U.S. Food, Drug Administration. Drugs\&FDA. www.accessdata.fda.gov/scripts/cder/drugsatfda/index.cfm? fuseaction=Search.label ${ }^{\circ}$ ApprovalHistory\#apphist (accessed and downloaded 15 July 2009).

\section{UKPDS 1998}

UK Prospective Diabetes Study (UKPDS) Group. Intensive blood-glucose control with sulphonylureas or insulin compared with conventional treatment and risk of complications in patients with type 2 diabetes (UKPDS 33). Lancet 1998;352:837-53.

\section{UKPDS-80 2008}

Holman RR, Paul SK, Bethel MA, Matthews DR, Neil HA. 10-year follow-up of intensive glucose control in type 2 diabetes. New England Journal of Medicine 2008;359: 1577-89.

\section{VADT 2009}

Duckworth W, Abraira C, Moritz T, Reda D, Emanuele N, Reaven PD, et al.Glucose control and vascular complications in veterans with type 2 diabetes. New England Journal of Medicine 2009;360:129-39.

\section{Weir 2004}

Weir GC, Weir-Bonner S. Five stages of evolving beta -cell dysfunction during progression to diabetes. Diabetes 2004; 53Suppl 3:16-21.

\section{WHO 1980}

WHO Expert Committee on Diabetes Mellitus. Second report. Technical Report Series 646. Geneva. WHO, 1980.

\section{WHO 1985}

WHO Expert Committee on Diabetes Mellitus. World Health Organization, 1985. Technical Report Series 727.

\section{WHO 1998}

Alberti KM, Zimmet PZ. Definition, diagnosis and classification of diabetes mellitus and its complications. Part I: diagnosis and classification of diabetes mellitus. Provisional report of a WHO consultation. Diabetic Medicine 1998;15:539-53.

* Indicates the major publication for the study 
ADDITIONAL TABLES

Table 1. Overview of study populations

\begin{tabular}{|c|c|c|c|c|c|c|c|c|}
\hline Study ID & $\begin{array}{l}\text { Interven- } \\
\operatorname{tion}(s) \quad \& x \\
\operatorname{control}(s)\end{array}$ & [n] screened & $\begin{array}{l}{[\mathbf{n}]} \\
\text { randomised }\end{array}$ & [n] safety & [n] ITT & $\begin{array}{l}\text { [n] finish- } \\
\text { ing study }\end{array}$ & $\begin{array}{l}\text { [\%] of ran- } \\
\text { domised } \\
\text { partici- } \\
\text { pants } \\
\text { finishing } \\
\text { study }\end{array}$ & Comments \\
\hline ID1 & $\begin{array}{l}\text { I1: } \\
\text { I2: } \\
\text { C1: } \\
\text { C2: }\end{array}$ & $\begin{array}{l}\text { I1: } \\
\text { I2: } \\
\text { C1: } \\
\text { C2: } \\
\text { Total: }\end{array}$ & $\begin{array}{l}\text { I1: } \\
\text { I2: } \\
\text { C1: } \\
\text { C2: } \\
\text { Total: }\end{array}$ & $\begin{array}{l}\text { I1: } \\
\text { I2: } \\
\text { C1: } \\
\text { C2: } \\
\text { Total: }\end{array}$ & $\begin{array}{l}\text { I1: } \\
\text { I2: } \\
\text { C1: } \\
\text { C2: } \\
\text { Total: }\end{array}$ & $\begin{array}{l}\text { I1: } \\
\text { I2: } \\
\text { C1: } \\
\text { C2: } \\
\text { Total: }\end{array}$ & $\begin{array}{l}\text { I1: } \\
\text { I2: } \\
\text { C1: } \\
\text { C2: } \\
\text { Total: }\end{array}$ & \\
\hline ID2 & $\begin{array}{l}\text { I1: } \\
\text { I2: } \\
\text { C1: } \\
\text { C2: }\end{array}$ & $\begin{array}{l}\text { I1: } \\
\text { I2: } \\
\text { C1: } \\
\text { C2: } \\
\text { Total: }\end{array}$ & $\begin{array}{l}\text { I1: } \\
\text { I2: } \\
\text { C1: } \\
\text { C2: } \\
\text { Total: }\end{array}$ & $\begin{array}{l}\text { I1: } \\
\text { I2: } \\
\text { C1: } \\
\text { C2: } \\
\text { Total: }\end{array}$ & $\begin{array}{l}\text { I1: } \\
\text { I2: } \\
\text { C1: } \\
\text { C2: } \\
\text { Total: }\end{array}$ & $\begin{array}{l}\text { I1: } \\
\text { I2: } \\
\text { C1: } \\
\text { C2: } \\
\text { Total: }\end{array}$ & $\begin{array}{l}\text { I1: } \\
\text { I2: } \\
\text { C1: } \\
\text { C2: } \\
\text { Total: }\end{array}$ & \\
\hline ID3 & $\begin{array}{l}\text { I1: } \\
\text { I2: } \\
\text { C1: } \\
\text { C2: }\end{array}$ & $\begin{array}{l}\text { I1: } \\
\text { I2: } \\
\text { C1: } \\
\text { C2: } \\
\text { Total: }\end{array}$ & $\begin{array}{l}\text { I1: } \\
\text { I2: } \\
\text { C1: } \\
\text { C2: } \\
\text { Total: }\end{array}$ & $\begin{array}{l}\text { I1: } \\
\text { I2: } \\
\text { C1: } \\
\text { C2: } \\
\text { Total: }\end{array}$ & $\begin{array}{l}\text { I1: } \\
\text { I2: } \\
\text { C1: } \\
\text { C2: } \\
\text { Total: }\end{array}$ & $\begin{array}{l}\text { I1: } \\
\text { I2: } \\
\text { C1: } \\
\text { C2: } \\
\text { Total: }\end{array}$ & $\begin{array}{l}\text { I1: } \\
\text { I2: } \\
\text { C1: } \\
\text { C2: } \\
\text { Total: }\end{array}$ & \\
\hline ID3 & $\begin{array}{l}\text { I1: } \\
\text { I2: } \\
\text { C1: } \\
\text { C2: }\end{array}$ & $\begin{array}{l}\text { I1: } \\
\text { I2: } \\
\text { C1: } \\
\text { C2: } \\
\text { Total: }\end{array}$ & $\begin{array}{l}\text { I1: } \\
\text { I2: } \\
\text { C1: } \\
\text { C2: } \\
\text { Total: }\end{array}$ & $\begin{array}{l}\text { I1: } \\
\text { I2: } \\
\text { C1: } \\
\text { C2: } \\
\text { Total: }\end{array}$ & $\begin{array}{l}\text { I1: } \\
\text { I2: } \\
\text { C1: } \\
\text { C2: } \\
\text { Total: }\end{array}$ & $\begin{array}{l}\text { I1: } \\
\text { I2: } \\
\text { C1: } \\
\text { C2: } \\
\text { Total: }\end{array}$ & $\begin{array}{l}\text { I1: } \\
\text { I2: } \\
\text { C1: } \\
\text { C2: } \\
\text { Total: }\end{array}$ & \\
\hline ID4 & $\begin{array}{l}\text { I1: } \\
\text { I2: } \\
\text { C1: } \\
\text { C2: }\end{array}$ & $\begin{array}{l}\text { I1: } \\
\text { I2: } \\
\text { C1: } \\
\text { C2: } \\
\text { Total: }\end{array}$ & $\begin{array}{l}\text { I1: } \\
\text { I2: } \\
\text { C1: } \\
\text { C2: } \\
\text { Total: }\end{array}$ & $\begin{array}{l}\text { I1: } \\
\text { I2: } \\
\text { C1: } \\
\text { C2: } \\
\text { Total: }\end{array}$ & $\begin{array}{l}\text { I1: } \\
\text { I2: } \\
\text { C1: } \\
\text { C2: } \\
\text { Total: }\end{array}$ & $\begin{array}{l}\text { I1: } \\
\text { I2: } \\
\text { C1: } \\
\text { C2: } \\
\text { Total: }\end{array}$ & $\begin{array}{l}\text { I1: } \\
\text { I2: } \\
\text { C1: } \\
\text { C2: } \\
\text { Total: }\end{array}$ & \\
\hline ID5 & $\begin{array}{l}\text { I1: } \\
\text { I2: } \\
\text { C1: } \\
\text { C2: }\end{array}$ & $\begin{array}{l}\text { I1: } \\
\text { I2: } \\
\text { C1: } \\
\text { C2: } \\
\text { Total: }\end{array}$ & $\begin{array}{l}\text { I1: } \\
\text { I2: } \\
\text { C1: } \\
\text { C2: } \\
\text { Total: }\end{array}$ & $\begin{array}{l}\text { I1: } \\
\text { I2: } \\
\text { C1: } \\
\text { C2: } \\
\text { Total: }\end{array}$ & $\begin{array}{l}\text { I1: } \\
\text { I2: } \\
\text { C1: } \\
\text { C2: } \\
\text { Total: }\end{array}$ & $\begin{array}{l}\text { I1: } \\
\text { I2: } \\
\text { C1: } \\
\text { C2: } \\
\text { Total: }\end{array}$ & $\begin{array}{l}\text { I1: } \\
\text { I2: } \\
\text { C1: } \\
\text { C2: } \\
\text { Total: }\end{array}$ & \\
\hline ID6 & $\begin{array}{l}\text { I1: } \\
\text { I2: } \\
\text { C1: } \\
\text { C2: }\end{array}$ & $\begin{array}{l}\text { I1: } \\
\text { I2: } \\
\text { C1: } \\
\text { C2: } \\
\text { Total: }\end{array}$ & $\begin{array}{l}\text { I1: } \\
\text { I2: } \\
\text { C1: } \\
\text { C2: } \\
\text { Total: }\end{array}$ & $\begin{array}{l}\text { I1: } \\
\text { I2: } \\
\text { C1: } \\
\text { C2: } \\
\text { Total: }\end{array}$ & $\begin{array}{l}\text { I1: } \\
\text { I2: } \\
\text { C1: } \\
\text { C2: } \\
\text { Total: }\end{array}$ & $\begin{array}{l}\text { I1: } \\
\text { I2: } \\
\text { C1: } \\
\text { C2: } \\
\text { Total: }\end{array}$ & $\begin{array}{l}\text { I1: } \\
\text { I2: } \\
\text { C1: } \\
\text { C2: } \\
\text { Total: }\end{array}$ & \\
\hline
\end{tabular}




\begin{tabular}{|c|c|c|c|c|c|c|c|}
\hline ID7 & $\begin{array}{l}\text { I1: } \\
\text { I2: } \\
\text { C1: } \\
\text { C2: }\end{array}$ & $\begin{array}{l}\text { I1: } \\
\text { I2: } \\
\text { C1: } \\
\text { C2: } \\
\text { Total: }\end{array}$ & $\begin{array}{l}\text { I1: } \\
\text { I2: } \\
\text { C1: } \\
\text { C2: } \\
\text { Total: }\end{array}$ & $\begin{array}{l}\text { I1: } \\
\text { I2: } \\
\text { C1: } \\
\text { C2: } \\
\text { Total: }\end{array}$ & $\begin{array}{l}\text { I1: } \\
\text { I2: } \\
\text { C1: } \\
\text { C2: } \\
\text { Total: }\end{array}$ & $\begin{array}{l}\text { I1: } \\
\text { I2: } \\
\text { C1: } \\
\text { C2: } \\
\text { Total: }\end{array}$ & $\begin{array}{l}\text { I1: } \\
\text { I2: } \\
\text { C1: } \\
\text { C2: } \\
\text { Total: }\end{array}$ \\
\hline ID8 & $\begin{array}{l}\text { I1: } \\
\text { I2: } \\
\text { C1: } \\
\text { C2: }\end{array}$ & $\begin{array}{l}\text { I1: } \\
\text { I2: } \\
\text { C1: } \\
\text { C2: } \\
\text { Total: }\end{array}$ & $\begin{array}{l}\text { I1: } \\
\text { I2: } \\
\text { C1: } \\
\text { C2: } \\
\text { Total: }\end{array}$ & $\begin{array}{l}\text { I1: } \\
\text { I2: } \\
\text { C1: } \\
\text { C2: } \\
\text { Total: }\end{array}$ & $\begin{array}{l}\text { I1: } \\
\text { I2: } \\
\text { C1: } \\
\text { C2: } \\
\text { Total: }\end{array}$ & $\begin{array}{l}\text { I1: } \\
\text { I2: } \\
\text { C1: } \\
\text { C2: } \\
\text { Total: }\end{array}$ & $\begin{array}{l}\text { I1: } \\
\text { I2: } \\
\text { C1: } \\
\text { C2: } \\
\text { Total: }\end{array}$ \\
\hline ID9 & $\begin{array}{l}\text { I1: } \\
\text { I2: } \\
\text { C1: } \\
\text { C2: }\end{array}$ & $\begin{array}{l}\text { I1: } \\
\text { I2: } \\
\text { C1: } \\
\text { C2: } \\
\text { Total: }\end{array}$ & $\begin{array}{l}\text { I1: } \\
\text { I2: } \\
\text { C1: } \\
\text { C2: } \\
\text { Total: }\end{array}$ & $\begin{array}{l}\text { I1: } \\
\text { I2: } \\
\text { C1: } \\
\text { C2: } \\
\text { Total: }\end{array}$ & $\begin{array}{l}\text { I1: } \\
\text { I2: } \\
\text { C1: } \\
\text { C2: } \\
\text { Total: }\end{array}$ & $\begin{array}{l}\text { I1: } \\
\text { I2: } \\
\text { C1: } \\
\text { C2: } \\
\text { Total: }\end{array}$ & $\begin{array}{l}\text { I1: } \\
\text { I2: } \\
\text { C1: } \\
\text { C2: } \\
\text { Total: }\end{array}$ \\
\hline Total & & & $\begin{array}{l}\text { I1: } \\
\text { I2: } \\
\text { C1: } \\
\text { C2: } \\
\text { Total: }\end{array}$ & & & $\begin{array}{l}\text { I1: } \\
\text { I2: } \\
\text { C1: } \\
\text { C2: } \\
\text { Total: }\end{array}$ & \\
\hline
\end{tabular}

C: control; I: intervention; ITT: intention-to-treat

\section{APPENDICES}

\section{Appendix I. Search strategies}

\section{Search terms}

Unless otherwise stated, search terms are free text terms; $\mathrm{MeSH}=$ Medical subject heading (Medline medical index term); exp = exploded $\mathrm{MeSH}$; the dollar sign $(\$)$ or asterisk $\left(^{*}\right)$ stand for any character(s); the question mark (?) = to substitute for one or no characters; $\mathrm{ab}=$ abstract; $\mathrm{adj}$ = adjacent; ot = original title; $\mathrm{pt}=$ publication type; $\mathrm{rn}=$ Registry number or Enzyme Commission number; $\mathrm{sh}=\mathrm{MeSH}$; $\mathrm{ti}=$ title; $\mathrm{tw}=$ text word

The Cochrane Library, Issue 3.2009

\#1 MeSH descriptor Diabetes Mellitus explode all trees

$\# 2$ (diabet*)

\#3 (IDDM or NIDDM or MODY or T1DM or T2DM)

\#4 (non insulin* depend* or noninsulin* depend* or non insulin?depend* or non insulin?depend*) 


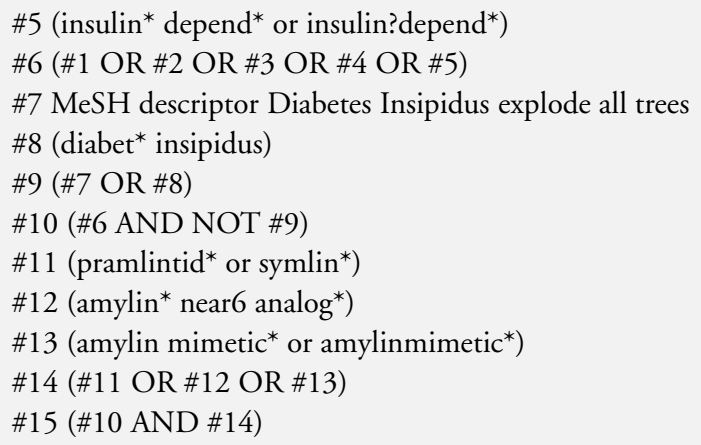

Medline (1950 to July Week 5 2009)

1. (pramlintid* or symlin*).tw,ot.

2. 151126-32-8.rn.

3. (amylin* adj6 analo?g*).tw,ot.

4. amylin?mimetic*.tw,ot.

5. or/ $1-4$

6. exp Diabetes Mellitus/

7. diabet*.tw,ot.

8. (IDDM or NIDDM or MODY or T1DM or T2DM).tw,ot.

9. (non insulin* depend* or noninsulin* depend* or non insulin?depend* or noninsulin?depend*).tw,ot.

10. (insulin* depend* or insulin?depend*).tw,ot.

11. exp Diabetes Insipidus/

12. diabet* insipidus.tw,ot.

13. or/6-10

14. 11 or 12

15. 13 not 14

16. 5 and 15

17. randomized controlled trial.pt.

18. controlled clinical trial.pt.

19. randomi?ed.ab.

20. placebo.ab.

21. drug therapy.fs.

22. randomly.ab.

23. trial.ab.

24. groups.ab.

25. or/17-24

26. Meta-analysis.pt.

27. exp Review/

28. exp Technology Assessment, Biomedical/

29. exp Meta-analysis as topic/

30. hta.tw,ot.

31. (health technology adj6 assessment ${ }^{*}$ ).tw,ot.

32. (meta analy* or metaanaly* or meta?analy*).tw,ot.

33. ((review* or search $\left.^{*}\right)$ adj10 (literature* or medical database* or medline or pubmed or embase or cochrane or cinahl or psycinfo or psyclit or healthstar or biosis or current content* or systemat $\left.{ }^{*}\right)$ ).tw,ot.

34. or/26-33 
35. (comment or editorial or historical-article).pt.

36. 34 not 35

37. 25 or 36

38. 16 and 37

39. (animals not (animals and humans)).tw,ot.

40.38 not 39

\section{EMBASE (EMBASE <1980 to 2009 August 5)}

1. exp pramlintide/

2. (pramlintid* or symlin*).tw,ot.

3. (amylin* adj6 analog*).tw,ot.

4. amylin?mimetic*.tw,ot.

5. or/1-4

6. exp Diabetes Mellitus/

7. diabet*.tw,ot.

8. (non insulin* depend* or noninsulin* depend* or non insulin?depend* or noninsulin?depend*).tw,ot.

9. (insulin* depend* or insulin?depend*).tw,ot.

10. (IDDM or NIDDM or MODY or T1DM or T2DM or T1d or T2D).tw,ot.

11. or/6-10

12. exp Diabetes Insipidus/

13. diabet* insipidus.tw,ot.

14. 12 or 13

15. 11 not 14

16. 5 and 15

17. exp Randomized Controlled Trial/

18. exp Controlled Clinical Trial/

19. exp Clinical Trial/

20. exp Comparative Study/

21. exp Drug comparison/

22. exp Randomization/

23. exp Crossover procedure/

24. exp Double blind procedure/

25. exp Single blind procedure/

26. exp Placebo/

27. exp Prospective Study/

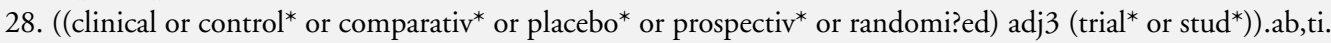

29. (random* adj6 (allocat* or assign* or basis or order*)).ab,ti.

30. ((singl ${ }^{*}$ or doubl* ${ }^{*}$ or trebl* or tripl* $\left.{ }^{*}\right)$ adj6 (blind* or mask*) ${ }^{*}$.ab,ti.

31. (cross over or crossover).ab,ti.

32. or/17-31

33. exp meta analysis/

34. (metaanaly* or meta analy* or meta?analy*).ab,ti,ot.

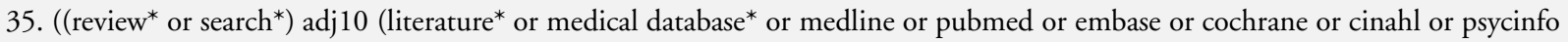
or psyclit or healthstar or biosis or current content* or systematic*)).ab,ti,ot.

36. exp Literature/

37. exp Biomedical Technology Assessment/

38. hta.tw,ot.

39. (health technology adj6 assessment ${ }^{*}$ ).tw,ot. 
40. or/33-39

41. (comment or editorial or historical-article).pt.

42. 40 not 41

43.32 or 42

44.16 and 43

45. limit 44 to human

\section{Appendix 2. Description of interventions}

\begin{tabular}{|c|c|c|c|c|c|c|c|c|c|}
\hline $\begin{array}{l}\text { Charac- } \\
\text { teristic }\end{array}$ & study ID1 & study ID2 & study ID3 & study ID4 & study ID5 & study ID6 & study ID7 & study ID8 & study ID9 \\
\hline $\begin{array}{l}\text { Interven- } \\
\text { tion(s) } \\
\text { [route, fre- } \\
\text { quency, to- } \\
\text { tal dose/ } \\
\text { day] }\end{array}$ & $\begin{array}{l}\text { I1: } \\
\text { I2: }\end{array}$ & $\begin{array}{l}\text { I1: } \\
\text { I2: }\end{array}$ & $\begin{array}{l}\text { I1: } \\
\text { I2: }\end{array}$ & $\begin{array}{l}\text { I1: } \\
\text { I2: }\end{array}$ & $\begin{array}{l}\text { I1: } \\
\text { I2: }\end{array}$ & $\begin{array}{l}\text { I1: } \\
\text { I2: }\end{array}$ & $\begin{array}{l}\text { I1: } \\
\text { I2: }\end{array}$ & $\begin{array}{l}\text { I1: } \\
\text { I2: }\end{array}$ & $\begin{array}{l}\text { I1: } \\
\text { I2: }\end{array}$ \\
\hline $\begin{array}{l}\text { Control(s) } \\
\text { [route, fre- } \\
\text { quency, to- } \\
\text { tal dose/ } \\
\text { day] }\end{array}$ & $\begin{array}{l}\mathrm{C} 1: \\
\mathrm{C} 2:\end{array}$ & $\begin{array}{l}\mathrm{C} 1: \\
\mathrm{C} 2:\end{array}$ & $\begin{array}{l}\text { C1: } \\
\text { C2: }\end{array}$ & $\begin{array}{l}\text { C1: } \\
\text { C2: }\end{array}$ & $\begin{array}{l}\text { C1: } \\
\text { C2: }\end{array}$ & $\begin{array}{l}\text { C1: } \\
\text { C2: }\end{array}$ & $\begin{array}{l}\text { C1: } \\
\text { C2: }\end{array}$ & $\begin{array}{l}\text { C1: } \\
\text { C2: }\end{array}$ & $\begin{array}{l}\text { C1: } \\
\text { C2: }\end{array}$ \\
\hline $\begin{array}{l}\text { Footnotes } \\
\text { C: control; I }\end{array}$ & : interventior & & & & & & & & \\
\hline
\end{tabular}

Appendix 3. Baseline characteristics

\begin{tabular}{|c|c|c|c|c|c|c|c|c|c|}
\hline $\begin{array}{l}\text { Charac- } \\
\text { teristic }\end{array}$ & study ID1 & study ID2 & study ID3 & study ID4 & study ID5 & study ID6 & study ID7 & study ID8 & study ID9 \\
\hline $\begin{array}{l}\text { Interven- } \\
\text { tion(s) \& } \\
\text { control(s) }\end{array}$ & $\begin{array}{l}\text { I1: } \\
\text { I2: } \\
\text { C1: } \\
\text { C2: }\end{array}$ & $\begin{array}{l}\text { I1: } \\
\text { I2: } \\
\text { C1: } \\
\text { C2: }\end{array}$ & $\begin{array}{l}\text { I1: } \\
\text { I2: } \\
\text { C1: } \\
\text { C2: }\end{array}$ & $\begin{array}{l}\text { I1: } \\
\text { I2: } \\
\text { C1: } \\
\text { C2: }\end{array}$ & $\begin{array}{l}\text { I1: } \\
\text { I2: } \\
\text { C1: } \\
\text { C2: }\end{array}$ & $\begin{array}{l}\text { I1: } \\
\text { I2: } \\
\text { C1: } \\
\text { C2: }\end{array}$ & $\begin{array}{l}\text { I1: } \\
\text { I2: } \\
\text { C1: } \\
\text { C2: }\end{array}$ & $\begin{array}{l}\text { I1: } \\
\text { I2: } \\
\text { C1: } \\
\text { C2: }\end{array}$ & $\begin{array}{l}\text { I1: } \\
\text { I2: } \\
\text { C1: } \\
\text { C2: }\end{array}$ \\
\hline
\end{tabular}

Participating population 


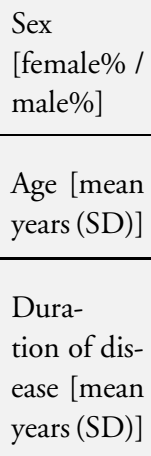

HbA1c

[mean \%

(SD)]

BMI

[mean kg/

$\left.\mathrm{m}^{2}(\mathrm{SD})\right]$

Ethnic

groups [\%]

Dura-

tion of in-

tervention

Dura-

tion of fol-

low up

Footnotes

BMI: body mass index; C: control; HbA1c: glycosylated haemoglobin A1c; I: intervention

Appendix 4. Matrix of study endpoints

\begin{tabular}{|c|c|c|c|c|c|c|c|c|c|}
\hline $\begin{array}{l}\text { Charac- } \\
\text { teristic }\end{array}$ & study ID1 & study ID2 & study ID3 & study ID4 & study ID5 & study ID6 & study ID7 & study ID8 & study ID9 \\
\hline $\begin{array}{l}\text { Interven- } \\
\text { tion(s) \& } \\
\text { control(s) }\end{array}$ & $\begin{array}{l}\text { I1: } \\
\text { I2: } \\
\text { C1: } \\
\text { C2: }\end{array}$ & $\begin{array}{l}\text { I1: } \\
\text { I2: } \\
\text { C1: } \\
\text { C2: }\end{array}$ & $\begin{array}{l}\text { I1: } \\
\text { I2: } \\
\text { C1: } \\
\text { C2: }\end{array}$ & $\begin{array}{l}\text { I1: } \\
\text { I2: } \\
\text { C1: } \\
\text { C2: }\end{array}$ & $\begin{array}{l}\text { I1: } \\
\text { I2: } \\
\text { C1: } \\
\text { C2: }\end{array}$ & $\begin{array}{l}\text { I1: } \\
\text { I2: } \\
\text { C1: } \\
\text { C2: }\end{array}$ & $\begin{array}{l}\text { I1: } \\
\text { I2: } \\
\text { C1: } \\
\text { C2: }\end{array}$ & $\begin{array}{l}\text { I1: } \\
\text { I2: } \\
\text { C1: } \\
\text { C2: }\end{array}$ & $\begin{array}{l}\text { I1: } \\
\text { I2: } \\
\text { C1: } \\
\text { C2: }\end{array}$ \\
\hline
\end{tabular}




\begin{tabular}{l}
$\begin{array}{l}\text { Primary } \\
1 \text { endpoint } \\
(s)\end{array}$ \\
\hline $\begin{array}{l}\text { Secondary } \\
2 \text { endpoint } \\
(s)\end{array}$ \\
\hline $\begin{array}{l}\text { Other } \\
3 \text { endpoint } \\
(s)\end{array}$ \\
\hline $\begin{array}{l}\text { Footnotes } \\
1,2 \text { as stated in the publication; }\end{array}{ }^{3}$ not stated as primary or secondary endpoint $(s)$ in the publication \\
C: control; I: intervention
\end{tabular}

\section{Appendix 5. Adverse events}

\begin{tabular}{|c|c|c|c|c|c|c|c|c|c|}
\hline $\begin{array}{l}\text { Charac- } \\
\text { teristic }\end{array}$ & study ID1 & study ID2 & study ID3 & study ID4 & study ID5 & study ID6 & study ID7 & study ID8 & study ID9 \\
\hline $\begin{array}{l}\text { Interven- } \\
\text { tion }(s) \& \& \\
\text { control(s) }\end{array}$ & $\begin{array}{l}\text { I1: } \\
\text { I2: } \\
\text { C1: } \\
\text { C2: }\end{array}$ & $\begin{array}{l}\text { I1: } \\
\text { I2: } \\
\text { C1: } \\
\text { C2: }\end{array}$ & $\begin{array}{l}\text { I1: } \\
\text { I2: } \\
\text { C1: } \\
\text { C2: }\end{array}$ & $\begin{array}{l}\text { I1: } \\
\text { I2: } \\
\text { C1: } \\
\text { C2: }\end{array}$ & $\begin{array}{l}\text { I1: } \\
\text { I2: } \\
\text { C1: } \\
\text { C2: }\end{array}$ & $\begin{array}{l}\text { I1: } \\
\text { I2: } \\
\text { C1: } \\
\text { C2: }\end{array}$ & $\begin{array}{l}\text { I1: } \\
\text { I2: } \\
\text { C1: } \\
\text { C2: }\end{array}$ & $\begin{array}{l}\text { I1: } \\
\text { I2: } \\
\text { C1: } \\
\text { C2: }\end{array}$ & $\begin{array}{l}\text { I1: } \\
\text { I2: } \\
\text { C1: } \\
\text { C2: }\end{array}$ \\
\hline $\begin{array}{l}\text { Deceased } \\
\text { partici- } \\
\text { pants }[\mathrm{n}]\end{array}$ & $\begin{array}{l}\text { I1: n / N } \\
\text { I2: } \\
\text { C1: } \\
\text { C2: } \\
\text { Total: }\end{array}$ & $\begin{array}{l}\text { I1: } \\
\text { I2: } \\
\text { C1: } \\
\text { C2: } \\
\text { Total: }\end{array}$ & $\begin{array}{l}\text { I1: } \\
\text { I2: } \\
\text { C1: } \\
\text { C2: } \\
\text { Total: }\end{array}$ & $\begin{array}{l}\text { I1: } \\
\text { I2: } \\
\text { C1: } \\
\text { C2: } \\
\text { Total: }\end{array}$ & $\begin{array}{l}\text { I1: } \\
\text { I2: } \\
\text { C1: } \\
\text { C2: } \\
\text { Total: }\end{array}$ & $\begin{array}{l}\text { I1: } \\
\text { I2: } \\
\text { C1: } \\
\text { C2: } \\
\text { Total: }\end{array}$ & $\begin{array}{l}\text { I1: } \\
\text { I2: } \\
\text { C1: } \\
\text { C2: } \\
\text { Total: }\end{array}$ & $\begin{array}{l}\text { I1: } \\
\text { I2: } \\
\text { C1: } \\
\text { C2: } \\
\text { Total: }\end{array}$ & $\begin{array}{l}\text { I1: } \\
\text { I2: } \\
\text { C1: } \\
\text { C2: } \\
\text { Total: }\end{array}$ \\
\hline $\begin{array}{l}\text { Adverse } \\
\text { events [n / } \\
\%]\end{array}$ & $\begin{array}{l}\text { I1: } \\
\text { I2: } \\
\text { C1: } \\
\text { C2: } \\
\text { Total: }\end{array}$ & $\begin{array}{l}\text { I1: } \\
\text { I2: } \\
\text { C1: } \\
\text { C2: } \\
\text { Total: }\end{array}$ & $\begin{array}{l}\text { I1: } \\
\text { I2: } \\
\text { C1: } \\
\text { C2: } \\
\text { Total: }\end{array}$ & $\begin{array}{l}\text { I1: } \\
\text { I2: } \\
\text { C1: } \\
\text { C2: } \\
\text { Total: }\end{array}$ & $\begin{array}{l}\text { I1: } \\
\text { I2: } \\
\text { C1: } \\
\text { C2: } \\
\text { Total: }\end{array}$ & $\begin{array}{l}\text { I1: } \\
\text { I2: } \\
\text { C1: } \\
\text { C2: } \\
\text { Total: }\end{array}$ & $\begin{array}{l}\text { I1: } \\
\text { I2: } \\
\text { C1: } \\
\text { C2: } \\
\text { Total: }\end{array}$ & $\begin{array}{l}\text { I1: } \\
\text { I2: } \\
\text { C1: } \\
\text { C2: } \\
\text { Total: }\end{array}$ & $\begin{array}{l}\text { I1: } \\
\text { I2: } \\
\text { C1: } \\
\text { C2: } \\
\text { Total: }\end{array}$ \\
\hline $\begin{array}{l}\text { Serious ad- } \\
\text { verse } \\
\text { events [n / } \\
\% \text { ] }\end{array}$ & $\begin{array}{l}\text { I1: } \\
\text { I2: } \\
\text { C1: } \\
\text { C2: } \\
\text { Total: }\end{array}$ & $\begin{array}{l}\text { I1: } \\
\text { I2: } \\
\text { C1: } \\
\text { C2: } \\
\text { Total: }\end{array}$ & $\begin{array}{l}\text { I1: } \\
\text { I2: } \\
\text { C1: } \\
\text { C2: } \\
\text { Total: }\end{array}$ & $\begin{array}{l}\text { I1: } \\
\text { I2: } \\
\text { C1: } \\
\text { C2: } \\
\text { Total: }\end{array}$ & $\begin{array}{l}\text { I1: } \\
\text { I2: } \\
\text { C1: } \\
\text { C2: } \\
\text { Total: }\end{array}$ & $\begin{array}{l}\text { I1: } \\
\text { I2: } \\
\text { C1: } \\
\text { C2: } \\
\text { Total: }\end{array}$ & $\begin{array}{l}\text { I1: } \\
\text { I2: } \\
\text { C1: } \\
\text { C2: } \\
\text { Total: }\end{array}$ & $\begin{array}{l}\text { I1: } \\
\text { I2: } \\
\text { C1: } \\
\text { C2: } \\
\text { Total: }\end{array}$ & $\begin{array}{l}\text { I1: } \\
\text { I2: } \\
\text { C1: } \\
\text { C2: } \\
\text { Total: }\end{array}$ \\
\hline
\end{tabular}




\begin{tabular}{|c|c|c|c|c|c|c|c|c|c|}
\hline $\begin{array}{l}\text { Drop- } \\
\text { outs due to } \\
\text { adverse } \\
\text { events [n / } \\
\% \text { ] }\end{array}$ & $\begin{array}{l}\text { I1: } \\
\text { I2: } \\
\text { C1: } \\
\text { C2: } \\
\text { Total: }\end{array}$ & $\begin{array}{l}\text { I1: } \\
\text { I2: } \\
\text { C1: } \\
\text { C2: } \\
\text { Total: }\end{array}$ & $\begin{array}{l}\text { I1: } \\
\text { I2: } \\
\text { C1: } \\
\text { C2: } \\
\text { Total: }\end{array}$ & $\begin{array}{l}\text { I1: } \\
\text { I2: } \\
\text { C1: } \\
\text { C2: } \\
\text { Total: }\end{array}$ & $\begin{array}{l}\text { I1: } \\
\text { I2: } \\
\text { C1: } \\
\text { C2: } \\
\text { Total: }\end{array}$ & $\begin{array}{l}\text { I1: } \\
\text { I2: } \\
\text { C1: } \\
\text { C2: } \\
\text { Total: }\end{array}$ & $\begin{array}{l}\text { I1: } \\
\text { I2: } \\
\text { C1: } \\
\text { C2: } \\
\text { Total: }\end{array}$ & $\begin{array}{l}\text { I1: } \\
\text { I2: } \\
\text { C1: } \\
\text { C2: } \\
\text { Total: }\end{array}$ & $\begin{array}{l}\text { I1: } \\
\text { I2: } \\
\text { C1: } \\
\text { C2: } \\
\text { Total: }\end{array}$ \\
\hline $\begin{array}{l}\text { Hospital- } \\
\text { isation [n / } \\
\%]\end{array}$ & $\begin{array}{l}\text { I1: } \\
\text { I2: } \\
\text { C1: } \\
\text { C2: } \\
\text { Total: }\end{array}$ & $\begin{array}{l}\text { I1: } \\
\text { I2: } \\
\text { C1: } \\
\text { C2: } \\
\text { Total: }\end{array}$ & $\begin{array}{l}\text { I1: } \\
\text { I2: } \\
\text { C1: } \\
\text { C2: } \\
\text { Total: }\end{array}$ & $\begin{array}{l}\text { I1: } \\
\text { I2: } \\
\text { C1: } \\
\text { C2: } \\
\text { Total: }\end{array}$ & $\begin{array}{l}\text { I1: } \\
\text { I2: } \\
\text { C1: } \\
\text { C2: } \\
\text { Total: }\end{array}$ & $\begin{array}{l}\text { I1: } \\
\text { I2: } \\
\text { C1: } \\
\text { C2: } \\
\text { Total: }\end{array}$ & $\begin{array}{l}\text { I1: } \\
\text { I2: } \\
\text { C1: } \\
\text { C2: } \\
\text { Total: }\end{array}$ & $\begin{array}{l}\text { I1: } \\
\text { I2: } \\
\text { C1: } \\
\text { C2: } \\
\text { Total: }\end{array}$ & $\begin{array}{l}\text { I1: } \\
\text { I2: } \\
\text { C1: } \\
\text { C2: } \\
\text { Total: }\end{array}$ \\
\hline $\begin{array}{l}\text { Out-pa- } \\
\text { tient treat- } \\
\text { ment [n / } \\
\%]\end{array}$ & $\begin{array}{l}\text { I1: } \\
\text { I2: } \\
\text { C1: } \\
\text { C2: } \\
\text { Total: }\end{array}$ & $\begin{array}{l}\text { I1: } \\
\text { I2: } \\
\text { C1: } \\
\text { C2: } \\
\text { Total: }\end{array}$ & $\begin{array}{l}\text { I1: } \\
\text { I2: } \\
\text { C1: } \\
\text { C2: } \\
\text { Total: }\end{array}$ & $\begin{array}{l}\text { I1: } \\
\text { I2: } \\
\text { C1: } \\
\text { C2: } \\
\text { Total: }\end{array}$ & $\begin{array}{l}\text { I1: } \\
\text { I2: } \\
\text { C1: } \\
\text { C2: } \\
\text { Total: }\end{array}$ & $\begin{array}{l}\text { I1: } \\
\text { I2: } \\
\text { C1: } \\
\text { C2: } \\
\text { Total: }\end{array}$ & $\begin{array}{l}\text { I1: } \\
\text { I2: } \\
\text { C1: } \\
\text { C2: } \\
\text { Total: }\end{array}$ & $\begin{array}{l}\text { I1: } \\
\text { I2: } \\
\text { C1: } \\
\text { C2: } \\
\text { Total: }\end{array}$ & $\begin{array}{l}\text { I1: } \\
\text { I2: } \\
\text { C1: } \\
\text { C2: } \\
\text { Total: }\end{array}$ \\
\hline $\begin{array}{l}\text { Hypogly- } \\
\text { caemic } \\
\text { episodes [n } \\
\text { /\%] }\end{array}$ & $\begin{array}{l}\text { I1: } \\
\text { I2: } \\
\text { C1: } \\
\text { C2: } \\
\text { Total: }\end{array}$ & $\begin{array}{l}\text { I1: } \\
\text { I2: } \\
\text { C1: } \\
\text { C2: } \\
\text { Total: }\end{array}$ & $\begin{array}{l}\text { I1: } \\
\text { I2: } \\
\text { C1: } \\
\text { C2: } \\
\text { Total: }\end{array}$ & $\begin{array}{l}\text { I1: } \\
\text { I2: } \\
\text { C1: } \\
\text { C2: } \\
\text { Total: }\end{array}$ & $\begin{array}{l}\text { I1: } \\
\text { I2: } \\
\text { C1: } \\
\text { C2: } \\
\text { Total: }\end{array}$ & $\begin{array}{l}\text { I1: } \\
\text { I2: } \\
\text { C1: } \\
\text { C2: } \\
\text { Total: }\end{array}$ & $\begin{array}{l}\text { I1: } \\
\text { I2: } \\
\text { C1: } \\
\text { C2: } \\
\text { Total: }\end{array}$ & $\begin{array}{l}\text { I1: } \\
\text { I2: } \\
\text { C1: } \\
\text { C2: } \\
\text { Total: }\end{array}$ & $\begin{array}{l}\text { I1: } \\
\text { I2: } \\
\text { C1: } \\
\text { C2: } \\
\text { Total: }\end{array}$ \\
\hline $\begin{array}{l}\text { Se- } \\
\text { vere hypo- } \\
\text { glycaemic } \\
\text { episodes [n } \\
\text { / \%] }\end{array}$ & $\begin{array}{l}\text { I1: } \\
\text { I2: } \\
\text { C1: } \\
\text { C2: } \\
\text { Total: }\end{array}$ & $\begin{array}{l}\text { I1: } \\
\text { I2: } \\
\text { C1: } \\
\text { C2: } \\
\text { Total: }\end{array}$ & $\begin{array}{l}\text { I1: } \\
\text { I2: } \\
\text { C1: } \\
\text { C2: } \\
\text { Total: }\end{array}$ & $\begin{array}{l}\text { I1: } \\
\text { I2: } \\
\text { C1: } \\
\text { C2: } \\
\text { Total: }\end{array}$ & $\begin{array}{l}\text { I1: } \\
\text { I2: } \\
\text { C1: } \\
\text { C2: } \\
\text { Total: }\end{array}$ & $\begin{array}{l}\text { I1: } \\
\text { I2: } \\
\text { C1: } \\
\text { C2: } \\
\text { Total: }\end{array}$ & $\begin{array}{l}\text { I1: } \\
\text { I2: } \\
\text { C1: } \\
\text { C2: } \\
\text { Total: }\end{array}$ & $\begin{array}{l}\text { I1: } \\
\text { I2: } \\
\text { C1: } \\
\text { C2: } \\
\text { Total: }\end{array}$ & $\begin{array}{l}\text { I1: } \\
\text { I2: } \\
\text { C1: } \\
\text { C2: } \\
\text { Total: }\end{array}$ \\
\hline
\end{tabular}

Defini-

tion of se-

vere / seri-

ous hypo-

glycaemia

\begin{tabular}{|c|c|c|c|c|c|c|c|c|c|}
\hline $\begin{array}{l}\text { Noctur- } \\
\text { nal hypo- } \\
\text { glycaemic } \\
\text { episodes [n } \\
\text { /\%] }\end{array}$ & $\begin{array}{l}\text { I1: } \\
\text { I2: } \\
\text { C1: } \\
\text { C2: } \\
\text { Total: }\end{array}$ & $\begin{array}{l}\text { I1: } \\
\text { I2: } \\
\text { C1: } \\
\text { C2: } \\
\text { Total: }\end{array}$ & $\begin{array}{l}\text { I1: } \\
\text { I2: } \\
\text { C1: } \\
\text { C2: } \\
\text { Total: }\end{array}$ & $\begin{array}{l}\text { I1: } \\
\text { I2: } \\
\text { C1: } \\
\text { C2: } \\
\text { Total: }\end{array}$ & $\begin{array}{l}\text { I1: } \\
\text { I2: } \\
\text { C1: } \\
\text { C2: } \\
\text { Total: }\end{array}$ & $\begin{array}{l}\text { I1: } \\
\text { I2: } \\
\text { C1: } \\
\text { C2: } \\
\text { Total: }\end{array}$ & $\begin{array}{l}\text { I1: } \\
\text { I2: } \\
\text { C1: } \\
\text { C2: } \\
\text { Total: }\end{array}$ & $\begin{array}{l}\text { I1: } \\
\text { I2: } \\
\text { C1: } \\
\text { C2: } \\
\text { Total: }\end{array}$ & $\begin{array}{l}\text { I1: } \\
\text { I2: } \\
\text { C1: } \\
\text { C2: } \\
\text { Total: }\end{array}$ \\
\hline $\begin{array}{l}\text { Symptoms } \\
{[\mathrm{n} / \%]}\end{array}$ & $\begin{array}{l}\text { I1: } \\
\text { I2: } \\
\text { C1: } \\
\text { C2: } \\
\text { Total: }\end{array}$ & $\begin{array}{l}\text { I1: } \\
\text { I2: } \\
\text { C1: } \\
\text { C2: } \\
\text { Total: }\end{array}$ & $\begin{array}{l}\text { I1: } \\
\text { I2: } \\
\text { C1: } \\
\text { C2: } \\
\text { Total: }\end{array}$ & $\begin{array}{l}\text { I1: } \\
\text { I2: } \\
\text { C1: } \\
\text { C2: } \\
\text { Total: }\end{array}$ & $\begin{array}{l}\text { I1: } \\
\text { I2: } \\
\text { C1: } \\
\text { C2: } \\
\text { Total: }\end{array}$ & $\begin{array}{l}\text { I1: } \\
\text { I2: } \\
\text { C1: } \\
\text { C2: } \\
\text { Total: }\end{array}$ & $\begin{array}{l}\text { I1: } \\
\text { I2: } \\
\text { C1: } \\
\text { C2: } \\
\text { Total: }\end{array}$ & $\begin{array}{l}\text { I1: } \\
\text { I2: } \\
\text { C1: } \\
\text { C2: } \\
\text { Total: }\end{array}$ & $\begin{array}{l}\text { I1: } \\
\text { I2: } \\
\text { C1: } \\
\text { C2: } \\
\text { Total: }\end{array}$ \\
\hline
\end{tabular}




\section{H IS T O R Y}

Protocol first published: Issue 2, 2010

\section{CONTRIBUTIONS OFAUTHORS}

DIANA H BARBONTA: protocol development, search for trials, selection of trials, risk of bias assessment in included trials, data extraction, data analysis, final review development.

CHRISTOPHER W LOUGHLAN: search for trials, selection of trials, risk of bias assessment in included trials, data extraction, data analysis, final review development.

CLAIRE DICKERSON: search for trials, selection of trials, risk of bias assessment in included trials, data analysis, final review development .

\section{DECLARATIONSOF INTEREST}

None known.

\section{SOURCES OF SUPPORT}

\section{Internal sources}

- No internal sources of support, Not specified.

\section{External sources}

- No external sources of support, Not specified.

\section{NOTES}

None. 